\title{
Humour generation and multimodal framing of political actor in the 2015 Nigerian presidential election campaign memes
}

\author{
Akin Tella \\ University of Ibadan, Nigeria \\ morakstell@yahoo.ca
}

\begin{abstract}
Internet memes significantly constitute an outlet for extensive popular political participation in election contexts. They instantiate humour and represent political candidates so as to affect voters' behaviour. Few studies on memes in political context exist (Shifman et al. 2007; Chen 2013; Tay 2014; Adegoju \& Oyebode 2015; Huttington 2016; Dzanic \& Berberovic 2017). These studies have not intensively examined the integrative deployment of visual and verbal resources afforded by internet memes to generate humour and to construct specific frames for election candidates in the campaign context of an emerging democracy. Therefore, this study investigates the use of language and visuals for humour generation and for the creation of definite frames for the two major presidential candidates in internet memes created in the course of the 2015 Nigerian presidential election campaigns. The theoretical insights for the study are derived from Attardo's (1997) set-up-incongruity-resolution theory of humour, Kuypers' (1997, 2002, 2009, 2010) model of rhetorical framing analysis, Bauman \& Briggs' (1990) concept of entextualisation, Kress \& van Leeuwen's (1996) socio-semiotic model for visual analysis and Sperber \& Wilson's (1986) relevance theory. The analysis indicates that meme producers generate humour and frame candidates through the entextualisation of verbal and visual texts, explicatures and implicatures. The memes construct seven individuated frames and one collective frame for the two major presidential candidates in the sampled memes using visual and linguistic resources. It concludes on the note that supporters of election candidates use humorous internet memes for negatively portraying opponents and for positive representation of the favoured candidate. These negative other-representations serve the purpose of depreciating the electoral values of the opponents and indirectly increasing the electoral chances of their own candidates.
\end{abstract}

Keywords: humour, multimodal framing, Nigeria, presidential election campaign, memes. 


\section{Introduction}

In a democratic framework, election campaigns provide an outlet for popular participation in the political process. The ascendancy of the Internet has provided another outlet for participation of voters in election campaigns. One major means that the Internet affords for the electorate is meme production. Dawkins introduced the word meme in his book The Selfish Gene (1976). Dawkins (1976), as cited in Shifman (2014: 9), defines memes as "small cultural units of transmission, analogous to genes, that spread from person to person by copying or imitation". Memes replicate fast as they undergo variation, competition, selection and retention. It is in relation to this that Dawkins discusses the idea of memetic co-adaptivity and meme complexes. A meme in the context of digital communication is called the internet meme. Shifman (2014: 41) describes an internet meme thus: "(a) a group of digital items sharing common characteristics of content, form, and/or stance, which (b) were created with awareness of each other, and (c) were circulated, imitated, and/or transformed via the Internet by many users". The definition underscores the major dimensions of meme (content, form, and stance) and the part human agency plays in the dissipation and transformation of internet memes.

Shifman (2013: 364-365) discusses such major attributes of the Internet meme as being a shared social phenomenon through transmission from one person to the other, being reproducible by means of imitation and being diffused through competition and selection. Structurally, memes take a variety of forms. Brideau \& Berret (2014) identify the imagemacro meme type. It usually comprises a superimposed written text over an image. The reaction Photoshop meme, which is the second, is marked by the use of Photoshop or related computer applications to remove an image from a setting and place it in another. Fundamentally, memes generate humour. But they also possess rhetorical values (Milner 2013). Based on its transmission and content alteration (in varying forms), by participants, Milner (2013) underscores the characterisation of memes as a participatory discourse form. Users signal their political affiliations, ideas, and ideological blocs by creating and contributing to memetic iteration on the Internet on campaign issues.

A number of studies have examined memes in political discourse from the perspectives of motivation for meme production and nature of memetic texts; the role of memes in instantiating political consciousness, setting political agenda and engaging in political criticism; and the discursive appropriation of memes in the representation of political candidates (Shifman et al. 2007; Chen 2013; Tay 2014; Adegoju \& Oyebode 2015; Huttington 2016; Dzanic \& Berberovic 2017). However, these studies have not intensively accounted for the unified deployment of visual and linguistic resources to create humour and construct specific frames for social actors in internet memes in the context of emerging African democracies. The closest to the present study in focus is Adegoju \& Oyebode (2015). It establishes humour as discursive resources for political representation with reference to the internet memes produced during the 2015 Nigerian presidential election campaign. However, it does not systematically categorise the representations and indicate the integrative appropriation of visual and verbal texts for the simultaneous creation of humour and construction of frames for electoral candidates.

Therefore, this study investigates the centripetal visual and verbal encoding of humour and specific frames for the two major presidential candidates in the internet memes produced during the 2015 Nigerian presidential election campaigns. The 2015 Nigerian presidential election was held on 28 March 2015. INEC registered eleven presidential candidates for the election. However, two of the candidates had towering presences compared to the others. They were the candidates of the All Progressives Congress (henceforth APC) and the People's Democratic Party (henceforth PDP). The candidates were Muhammadu Buhari and Goodluck 
Jonathan, respectively. APC was formed from an alliance of three opposition parties and a faction of the ruling party in February 2013. The PDP was the party in government. The PDP dominated the Nigerian political landscape from 1999 to 2015.

\section{Theoretical framework}

This study derives its theoretical perspectives from Attardo's (1997) set-up-incongruityresolution theory, Kuypers' (1997; 2002; 2009; 2010) model of rhetorical framing analysis, Bauman \& Briggs' (1990) concept of entextualisation, Kress \& van Leeuwen's (1996) sociosemiotic model for visual analysis, and Sperber \& Wilson's (1986) relevance theory. Theoretical insights from these were worked into an analytical model (which is schematically represented and discussed below) for the purpose of this study. The definition of humour adopted in this study combines well with the adopted theory of humour (i.e. the set upincongruity-resolution theory of humour) and the other major theoretical anchor, namely relevance theory. They all underscore the socio-cognitive dimension of meaning generation. Humour is the cognitive reaction to the incompatibility of a stimulus with expected patterns or properties. Essentially, logical inconsistencies drive humour. Attardo's (1997) set-upincongruity-resolution theory of humour accounts for the humorous contents of the sampled texts. The theory expands Raskin's (1985) script-based semantic theory of humour. Raskin (1985) states that a text derives its humour from its compatibility with two opposing scripts which overlap fully or partially. Scripts refer to "collections of semantic information pertaining to a given subject" (Attardo 1997: 403). Attardo (1997) regards the set-up phase as the instantiation of the first script. Scripts as components of memory are divisible into two classes: context-free scripts and context-bound scripts. The context-free scripts are shared by most speakers and are easier to access. The context-bound ones are instantiated only in relevant contexts. The instantiation of the first script continues until a reader or listener encounters the disjunctor which signals script opposition (or incongruity).

Attardo (1997: 398), citing Nerhardt (1976: 59), defines incongruity as the "divergence of a stimulus from expectation". Festinger's (1957) idea of cognitive dissonance birthed incongruity as a concept in the set up-incongruity-resolution model. The resolution phase follows the incongruity phase; it is the point of discovering the "sense in no-sense" (Freud (1960 [1905]), cited in Attardo 1997: 405). Humour emanates from the resolution of incongruity; the extent to which a stimulus generates humour depends on the rate to which it (the stimulus) diverges from expectation. The theory equates resolution with Local Mechanisms (LM) in Attardo \& Raskin's (1991) General Theory of Verbal Humour. Forms of LM include figure-ground, reversal, faulty logic, chiasmus, (false) analogy, false priming, and mere juxtaposition (Attardo \& Raskin 1991: 303-307).

This humour theory, aided by the concept of entextualisation, Kress \& van Leeuwen's (1996) socio-semiotic model for visual analysis, and Sperber \& Wilson's (1986) relevance theory is deployed to account for humour generation in this study. The set up-incongruityresolution theory of humour is preferred in this study because of its recognition of the centrality of the socio-cognitive context in humour generation. Its privileging of scripts and their opposition signals this. In addition, it offers a clear computational procedure for humour generation. Its recognition of the centrality of context and its proposal for a procedure for computing humour makes it compatible with the other major theories for the study (i.e. framing theory and relevance theory) and the concept of entextualisation.

Kuypers $(1997 ; 2002 ; 2009 ; 2010)$ presents a rhetorical version of framing analysis based on combined insights from rhetorical criticism and framing analysis. Rhetorical framing analysis involves studying how the choices of communicators from language and other 
semiotic systems direct the decoder's interpretive efforts. Communicators achieve rhetorical framing by focusing decoders' attention on a particular part of an issue and by attributing qualities to social actors or situations. It typically proceeds from identifying the themes (and the social actors involved in them) in a text and determining how the themes or the indicated actors are framed (see Kuypers 1997; 2002; Kuypers et al. 2008 for sample analyses). In determining the themes of a text and their frames, rhetorical framing analysis emphasises the role of contextual variables. Framing of situations and social actors involved in them is based on identifying specific and consistent discourse properties such as keywords, metaphors, concepts, symbols, visuals, labels (Entman 1991:7). This study prefers the rhetorical framing analysis model because it takes into cognisance the salience of linguistic items and other communicative modes, and the role of context in determining frames. Besides, its foregrounding of the rhetorical imports of frames helps to account for the persuasive functions (beyond the instantiation of humour) of the identified frames in context.

Entextualisation accounts for the production trajectories of the memes and how they engender humour and the multimodal framing of social actors. Entextualisation involves the process of capturing discourse as text. The reduction of discourse to text engenders its removal from its original setting (decontextualisation) and its fixation in a novel discourse context (recontextualisation) (Bauman \& Briggs 1990: 73; Giaxoglou 2009: 420-422). Entextualisation affords the meaningfulness of a text across spatio-temporal frames. This accords potential transferability in new contexts (recontexualisation) to texts (Silverstein \& Urban 1996: 1-17). The examined memes feature the contextual transposition of their components (verbal and visual aspects; and their attendant explicit and implicit meanings). The concept of entextualisation serves to explain the process of this in the selected election campaign memes and their attendant implications for humour creation and framing of social actors. It fundamentally complements the set up-incongruity-resolution model in accounting for humour and Kuypers' $(1997 ; 2002 ; 2009 ; 2010)$ model of rhetorical framing analysis in accounting for the rhetorical framing of the political actors.

Since memes are multimodal texts, this study utilises Kress \& van Leeuwen's (1996) socio-semiotic model for visual analysis to account for the visual resources with which the frames are established in the memes. Unlike previous works in visual semiotics that examine the iconographical and iconological significances of visuals, this model presents a grammar of visual designs which describe the relations between depicted elements in images (Kress \& van Leeuwen 1996: 1). It builds on the identified metafunctions in Systemic Functional Linguistics (SFL) to account for meaningful relations among visual elements. It recognises three types of meaning: representational, compositional, and interactional meanings. Representational meaning relates to SFL's ideational metafunction. It houses narrative processes that account for what participants in visuals are represented as doing to or for each other, and conceptual processes which represent participants in terms of their essence or class.

Compositional meaning approximates to the textual metafunction in SFL; it accounts for how the placement of elements within an image foregrounds them. It comprises information value, salience (size, sharpness, tonal contrast, and perspective) and framing (presence or absence of juncture markers in a visual). Interactional meaning caters for the interpersonal perspective. It explains how visual text makers address the visual text to their receptors. The model also accounts for modality in visuality; it caters for the degree to which a verbal text is truthful or untruthful to the values and believes that the image communicates. This theoretical model is preferred on two grounds: it recognises that represented participants in images engage in processes and relate with one another; and it provides a holistic account of the interaction between images and written texts of multimodal texts.

Sperber \& Wilson's (1986) relevance theory is employed in this study to account for how explicatures and implicatures generate humour and frame political actors in the selected 
memes. The investigation prefers relevance theory as a theory of meaning explication because it offers a fairly comprehensive computational procedure for meaning generation. Its sociocognitive orientation makes it combinable with the selected humour and framing theories. Relevance theory conceives communication as 'ostensive-inferential' which ensues from the interaction of ostension and inference. The communicator indicates that they have something to communicate through ostension. The indication of informative intention precedes ostension. The communicator produces an ostensive stimulus that is mutually manifest. The communicator relies on shared knowledge between them and the audience before producing any stimuli. Based on the cognitive principle of relevance and the communicative principle of relevance, the communicator makes the stimuli as comprehensible as possible.

The cognitive principle of relevance states that "human cognition tends to be geared towards the maximization of relevance". The communicative principle of relevance holds that "every ostensive-stimulus conveys a presumption of its own optimal relevance" (Sperber \& Wilson 1986: 153). The communicator considers these principles in their creation of texts. The audience receives the stimuli and applies the principles to generate cognitive effects (meanings). The first point in the comprehension process is the extraction of logical forms. Logical forms are assumption schemas which are stored in memory or completed propositional forms that hearers' eventually further enrich. The derivation of logical forms is the context-free phase of utterance interpretation in relevance theory.

Next is the inferential development of logical forms through enrichment procedures like reference assignment, disambiguation, saturation, gap filling, lexical narrowing, and loosening (Blakemore 1992; Wilson 1994; Carston 2002; Yus 2003). Hearers also factor in a speaker's propositional attitude to determine the explicatures in utterances. Explicature refers to "an ostensively communicated assumption that is inferentially developed from one of the incomplete conceptual representations (logical forms) encoded by the utterance" (Carston 2002: 377). Other points in the comprehension process include determining the higher degree explicature, deriving the implicated premise and constructing the implicated conclusion. The audience stops the utterance processing procedure when it derives the most salient contextual interpretation of a stimulus (Blakemore 1992; Wilson 1994; Carston 2002; Yus 2003).

\section{Methodology}

Internet memes with campaign contents for the 2015 Nigerian presidential election constitute the data for this study. Since the re-institution of democracy in Nigeria in 1999, no other election year in Nigeria seemed to have witnessed the same level of citizens' online participation in the election campaign discourse as the 2015 general elections. The generally high tempo of the 2015 Nigerian general elections and the increased use of the Internet by Nigerians account for this. A major shift in the pre-election context may have also accounted for the heightened campaign tempo: the period witnessed a coalition of two major political parties (the Action Congress [AC] and the Coalition for Progressive Change [CPC]) which aimed at displacing the incumbent People's Democratic Party (PDP) government.

The memes were collected from the following Nigerian internet sites: pulse.ng, olisa.tv, nairaland.com and buzznigeria.com. Nigerian election internet campaign memes contributed by the electorate (not candidates' campaign machinery) are variously mostly mediated by soft news sites, online fora, blog spots, and social media platforms. In the process of collecting the data for the current study, the researcher conducted a preliminary survey of online platforms with election campaign memes on the 2015 Nigerian presidential election. The survey indicated that soft news sites and online forums featured more memes than the other online outlets. In addition, soft news sites and online forums possess more easily accessible archives 
of featured past memes than the other sources. These informed the selection of the soft news sites and online forums as primary data sources. Furthermore, out of all the soft news sites and media fora surveyed, the selected ones featured more election campaign memes. Hence, their final selection as data sources. Forty-six (46) memes made up the data for the study. Using purposive sampling technique, we selected only the humorous memes. Their humorous contents were determined based on the concenptualisation of humour as logical incompatibility. Such memes amounted to nineteen (19). Three criteria guided the selection: being created during the campaign period, containing a campaign message for or against a presidential candidate, and being humorous in content.

Campaign speeches, posters, manifestoes, and advertorials serve as popular purveyors of election candidates' ideas in an electioneering context. A number of previous studies have elucidated the discourse features of these election campaign discourse forms and the communicative intentions of the politicians who deploy them. Much attention has not been devoted to how the citizenry contribute to election campaign discourse, especially through online election campaign memes. This is despite the densely communicative and creative contents of memes; meme creators combine both linguistic and visual cues to satirise political actors and express their dispositions towards them. As previously mentioned, the analysis itself was informed by the analytical model below which was built with theoretical outlooks from Attardo's (1997) set-up-incongruity-resolution theory of humour, Kuypers' $(1997 ; 2002$; 2009; 2010) model of rhetorical framing analysis, Bauman \& Briggs' (1990) concept of entextualisation, Kress \& van Leeuwen's (1996) socio-semiotic model for visual analysis and Sperber \& Wilson's (1986) relevance theory.

\section{Analytical model}

The schema below (p.101) represents the analytical model for the study. The encoding and decoding of humour and other rhetorical values in a meme rely on contextual information. The relevant aspects of the socio-cognitive context that aid memetic comprehension include context-free scripts on language and language use; icons, indexes, and symbols used as visuals; scriptures; international economic systems; election candidates' backgrounds; immediate election campaign issues, and the general Nigerian political culture. The socio-cognitive context with its context-free scripts informs the other forms of context (designated here as 'Context I' and 'Context II') which possess context-bound scripts. Every context possesses its own context-bound script(s) and every meme undergoes a transfer from one context to the election campaign context. The eventual creation of humour and comprehension of the latent communicative intentions of memes by its consumers involves their decoding the recontextualisation trajectory of the memes; every meme undergoes transposition from one context to another (as indicated in the diagram above by the thick arrow that represent the movement of 'Meme A' from one context to another). The location of Meme A within Context I represents the set-up phase.

Its recontextualisation into Context II (the election campaign context) stands as a precursor for script opposition (or incongruity). The detection of incongruity involves the interpretation of a meme in terms of the incompatibility (or otherwise) of its verbal and visual components, their explicit meanings and their presuppositions (which serve as disjunctors) with the new context within which the meme is situated. The incongruity results from the transference of the associated scripts with Context I with Meme A as it moves to Context II which possesses its different scripts. The script opposition is signalled in the schema above with the bold question mark after 'Meme A'. The incompatibility of a meme with the associated script of the context into which it is moved warrants the infusion of the context 
(into which the meme is moved) with more contextual information from the larger sociocognitive context. This is signposted by the bold and large arrow that connects the 'MacroContext' box to the 'Context II' box. This eventually leads to the realisation of the humorous intent of the meme's creator (the resolution phase) and derivation of the implicated conclusion of the meme which is its latent rhetorical intention. The derived implicature supports a particular (negative or positive) representation of the social actor(s) depicted in the memes. This representation is the frame.

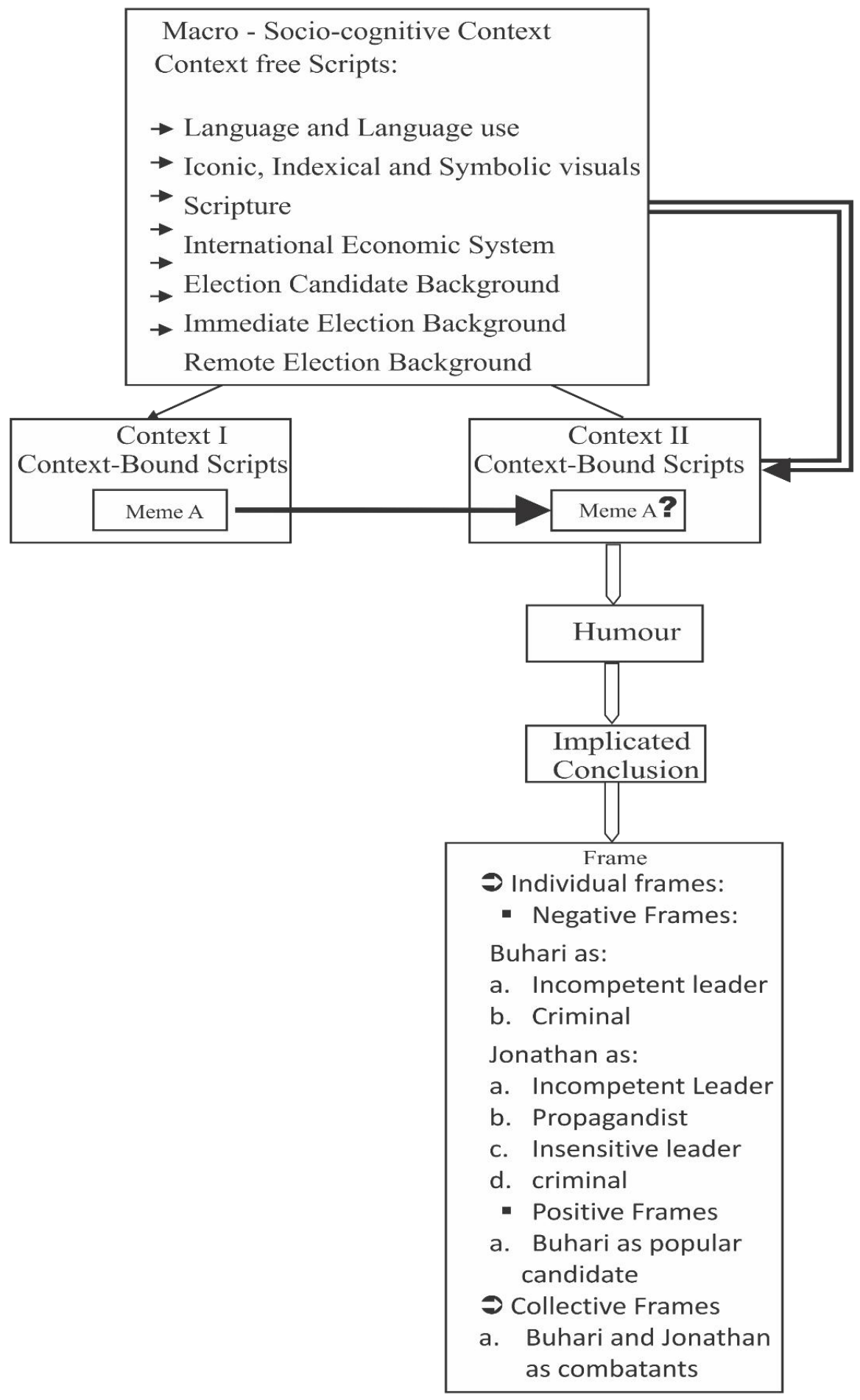

Figure 1. A schema representing an analytical model for election campaign memes 


\section{Data presentation and analysis}

The analysis below presents the different frames created for the two major political contenders in the 2015 Nigerian presidential election - Muhammadu Buhari of APC and Goodluck Jonathan of PDP - in the selected memes. The top-down mode of analysis is deployed. This section exemplifies how the visuals and the verbal contents in the memes generate humour and implicitly frame the two major contestants in the presidential election. Eight major frames of the two presidential candidates are projected in humorous election campaign memes of the 2015 Nigerian presidential election. The frames are classifiable into two major classes: individuated and collective frames.

\subsection{Individuated framing of political actors}

The individuated frames portray the candidates as separate identities and attribute negative or positive representations to them. The individuated frames bifurcate into two sub-branches: the negative frames and the positive frames. The six negative individuated frames (Buhari as incompetent candidate, Buhari as criminal, Jonathan as incompetent leader, Jonathan as propagandist, Jonathan as insensitive leader and Jonathan as criminal) represent the candidates negatively. The only positive individuated frame is Buhari as popular candidate.

\subsubsection{Negative individuated framing of political actors}

Through the six negative individuated frames, adversative contexts are created for the presidential candidates. Meme creators represent the candidates they favour positively but portray the candidates' opponents in political contests negatively. The parodying of others in a campaign context is intended to reduce their electoral values before the electorate. They magnify their weaknesses and vitiate their strong points. This trend seems to suggest that humorous political memes rests significantly on satirising of opposing political figures through the ascription of ridiculous actions, speeches, qualities, and intents (as in Texts 1-6) to them.

\subsubsection{Buhari as incompetent candidate}

An incompetent candidate lacks the requisite knowledge on vital national affairs and the capacity to proffer potent solutions and informed viewpoints on emerging national plights. In the sampled memes where Buhari is presented as an incompetent leader, he is portrayed as lacking the required knowledge on some economic operations because of insufficient formal education. Text 1 exemplifies the frame:

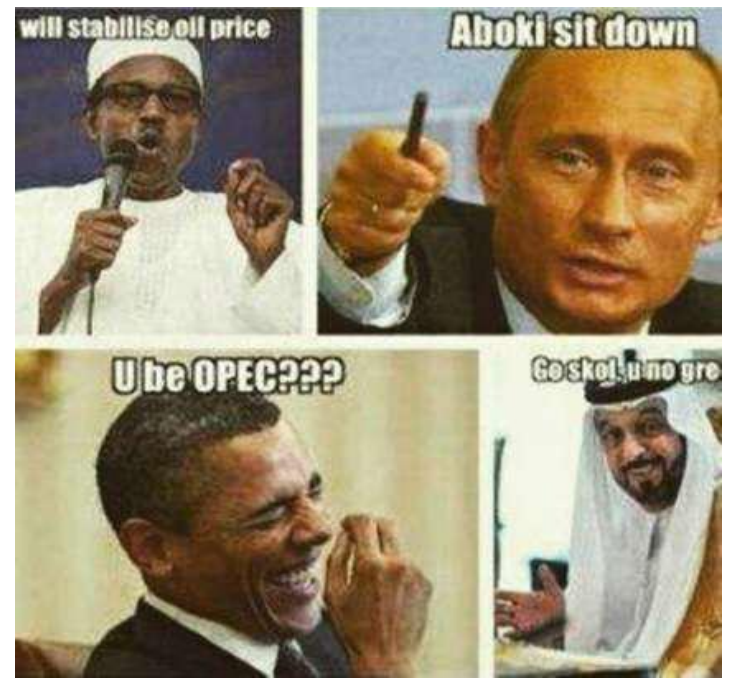

Text 1. Buhari as incompetent candidate. 
The meme maker employs entextualisation by importing the images of the world leaders from distinct contexts and putting them in the context of the Nigerian 2015 presidential election campaign discourse. The meme makes the social actors in them to interact as if they are in a single synchronous interaction. The meme presents Buhari as directly addressing the other depicted social actors who respond variously to his campaign point. Based on the cognitive environment that election campaign precedes every election, a reader construes the first of the four images as an instance of a campaign promise. The first image is an iconic representation of Muhammadu Buhari, the presidential candidate of APC in the Nigerian 2015 presidential election. Buhari engages in two narrative processes: the non-transactional action process of addressing Nigerians and the major world leaders depicted in the other images constituting the visual, and the speech process as signalled by the verbal text: I will stabilise oil price. $I$ as a definite token refers to Buhari who is depicted in the first image. The image serves as an iconic representation that aids assigning reference to $I$ in the meme. It refers to Muhammadu Buhari. Oil price makes a reference to crude oil price in the international market. The importation of crude oil has been the country's economic mainstay since the 1970s. So, its price in the world market significantly impacts the Nigerian economy. As at the year of the election campaign, crude oil price had become very low. It was reported to have been below $\$ 40$ per barrel, the lowest level it had fallen since 2009. Hence, it became a campaign issue in the election year. With the additional contextual information, oil price can be gap filled to give oil price in the international market. Combining gap filling with reference assignment, the derived explicature is: Buhari promises Nigerians to stabilise crude oil price in the international market.

The second photograph is that of the Russian leader, Vladmir Putin. Putin is regarded as a major political force in the world. Putin performs both a transactional reactional process and a speech process. The meme presents his speech as a reaction to Buhari's campaign point. Putin points at Buhari (though not directly towards him in the text) and instructs him (Buhari) to sit down. The content of the verbal text (Aboki, sit down!) indicates that Buhari is the targeted recipient of his speech and deictic gesture. To enrich the imperative, one employs bridging to determine the meaning of the indexical, Aboki. The lexeme belongs to Hausa, one of Nigeria's major languages. It denotes "friend" in Hausa. However, ethnic groups in southern Nigeria have semantically extended and pejorated it to mean being a nitwit. The only participant from northern Nigeria in the visual is Buhari. So, the meme deploys Aboki as an invective term to refer to Buhari and Putin requires Buhari to sit down. Putin's reference to Buhari as Aboki resonates name-calling as a sub-branch of ethnic humour and achieves a humorous effect in this instance. This ethnic stereotyping fits the condemnatory stance of Putin towards Buhari's enunciation in the first image. In addition, Putin's commanding of Buhari to sit down has a humorous bend too. This instance of bridging and the propositional attitude of the speaker (as signalled by the imperative mood of the utterance and the act of pointing with a stern face) realise the explicature: Putin commanded Buhari to sit down. The implicated premise is that Buhari is standing up and campaigning to a population, and Putin is the moderator of the talk event. Given the imagined role allocation between Buhari and Putin (Buhari as campaigner and Putin as moderator) which the meme has constructed, the following implicated conclusion ensues: Buhari has enunciated a wrong idea.

The third part has the image of Barack Obama, who, at the time of the Nigerian presidential election campaign in 2015, was the American president. He undertakes the behavioural process of laughing as a reaction to Buhari's comment that he would stabilise international oil price. This reaction reveals his amusement about the content of Buhari's comment. This also reinforces Putin's conception of Buhari's comment as daffy. Obama also performs a mental process as indicated by the expression $U$ be OPEC?. This indicates what instantiates his laughter. The thought requires further explication through reference assignment 
and bridging. $U$ is the abbreviated form of you in cyber language. Here, it intratexually refers to Buhari whose image is in the first photograph. OPEC refers extratextually to the Organisation of Petroleum Exporting Countries, a cartel that coordinates and unifies the petroleum pricing policies of its member-states. The explicated meaning of the utterance is that OPEC, not Buhari, controls the international crude oil pricing system. The implicated premise is that OPEC exists as a cartel. The implicated conclusion is that Buhari does not have any deep knowledge about the international crude oil pricing system. In addition, the implied meaning of the thought ascribed to Obama indirectly explains why Putin directs Buhari to "sit down" in the second image; the campaign point he enunciates is not in consonance with the existing international mode of regulating crude oil price.

The behavioural reaction of Obama (his laughter) works as a non-linguistic prelude to linguistic humour generation in this meme. It points to the supposed ridiculousness in Buhari's campaign speech. The rhetorical tune of $U$ be OPEC? further satirises Buhari's campaign point. The rhetorical form of the utterance presents the fact that only OPEC regulates international oil price as a very obvious one that every aspiring public officer in an oilproducing nation which is a member of OPEC should know. That Buhari lacks the general knowledge of international crude oil pricing and seeks to govern a nation-state with an oil economy generates humour. The intentional code selection adds to the humour content and reinforces the instance of ethnic humour as presented above. The meme ascribes a pidgin expression to Barack Obama who is not a known speaker of Nigerian Pidgin and he addresses Buhari in pidgin to underscore his (Buhari's) identity as an uneducated being. This careful code selection reinforces the ethnic stereotype that Aboki carries and stands as a precursor to the next image's explicit construal of Buhari as an uneducated Nigerian.

The last image contains the picture of Salman bin Abdulaziz Al Saud, the King of Saudi Arabia. Here, he performs a non-transactional reactional process. Salman directly reacts to Buhari's campaign promise to stabilise oil price. Salman performs two gestures: he (Salman) smiles at Buhari and opens and extends his right palm to underscore the obviousness of a consequence he had warned against. The attributed speech shows the obvious consequence of Buhari's refusal to heed a piece of advice or warning issued in the past to him. The utterance attributed to Salman is Go skol u no gree. This Nigerian pidgin expression roughly translates as We told you to go to school but you refused. In terms of reference assignment, We is an indefinite token that refers to all those who oppose Buhari's candidature on the basis of his being less educated. You refers intratextually to Buhari and school works as an indefinite token that means an institution of higher learning. Buhari ruled Nigeria as a military head of state from 1983 to 1985 . He was admitted into the Nigerian Army based on his possession of a secondary education certificate. Therefore, it is not that he never went to school. It is that he never attended a higher institution. The explicatural meaning of the utterance is Buhari did not attend a higher institution.

The implicated premise is that the speaker had enjoined Buhari to attend a formal higher institution but Buhari refused to heed the advice. The implied meaning is Buhari does not know how cartels function because he lacks the general knowledge of economic operations that most graduates of higher institutions have. The final contextual implication counters one's expectation about who should be considered as a serious contender for the nation's presidency. A conscientious candidate requires deep knowledge of the economic system of a country that he seeks to rule. That Buhari does not possess such knowledge and he is the candidate of a major political party instantiates humour, too.

Based on the implicated conclusions of the images above, Buhari is framed as an incompetent leader. Every aspiring Nigerian leader is expected to know how the nation's economic mainstay (i.e. crude oil exportation) works. Buhari is presented as not possessing the requisite knowledge on how this crucial sector of the economy works. The meme further 
legitimises the frame through one discourse strategy and two visual composition features. Through the attribution of the speeches condemning Buhari as an ignoramus to major world leaders such as Barack Obama, Vladimir Putin and King Salman, the meme validates its frame. This discursive strategy is personal authorisation (van Leeuwen 2008: 106; Filani 2016: 20). The separate frames used for the four photographs, through demarcation by white lines and discontinuity of colour, indicate that the entities made their assessments of Buhari's campaign promise separately; none influenced the other to say what he says. This helps to achieve multiplicity of sources as an evaluative strategy (Martin \& White 2005: 116). Buhari's criticism as an incompetent leader is cross-continental; it is across North America, Europe and the Arab World.

\subsubsection{Buhari as criminal}

Some memes portray Buhari as a criminal in relation to his alleged inability to present his school leaving certificate, as required by constitutional provisions, and swearing falsely to an affidavit claiming that his certificates were with the Military Board, namely a non-existent organ in the Nigerian military. The case brought against him on this was later struck out by a court of law before the election (Nnochiri 2015). Text 2 below illustrates the frame:

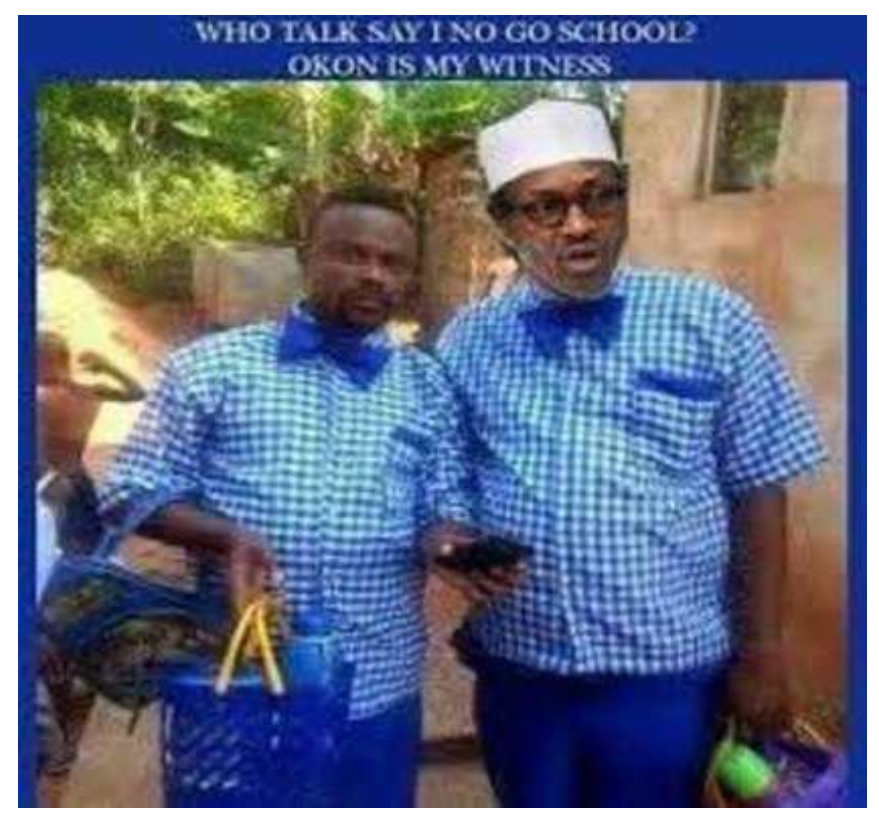

Text 2. Buhari as criminal.

This meme works more on entextualisation. The meme creator recontextualises the visuals through the deployment of Photoshop. The images seemed to have been obtained from a Nigerian home video in which Okon (Bishop Emem) and another artiste acted as school children. To achieve the textual transposition from that entertainment context to the election campaign context, the meme producer edits the image of the second actor by replacing his head with that of Buhari. There are two participants in the meme and both wear a school uniform and carry plastic baskets containing their food flasks like most Nigerian children of school age do. In terms of narrative process, they both perform the non-transactional reactional process of gazing outside the visual.

To establish their construal here as school children, the background contains a school building to the right and some playing school children to the left. To achieve prominence for both participants, they are placed at the centre of the frame and captured by a medium long 
shot. Their visual presentation as school children works as the first point of humour generation. Its being counterfactual engenders humour. The two participants, as depicted, have grown beyond school age. The picture does not represent them as children. Rather, it construes them as adults in school uniforms. Their depicted age and size contravene our factual assumptions about the size and age of school children.

Through the speech process, an utterance is attributed to Buhari. The attributed utterance is "Who talk say I no go school? Okon is my witness". Some expressions in the utterance require further enrichment through reference assignment. One of the main campaign issues used by the PDP against the APC candidate was that he did not possess the educational requirements stipulated by the constitution to contest as Nigeria's president. I and Okon refer intratextually to Buhari and the popular Nigerian comedian with whom he stands in the visual. His real name is Bishop Emem but his stage name is Okon. School stands as an indefinite token which refers to any educational outfit. The explicatural analysis, when taken together with the visual (which works as an evidential that Buhari attended a school), yields the explicature here: Buhari and Okon were classmates. The explicature leads to the implicated premise: if Okon and Buhari were classmates, Buhari attended a school. The explicated meaning and the implicated premise engender humour because they counter some established scripts. The significant age difference between Okon and Buhari negates their being nursery or primary school classmates. Buhari is in his 70s and Okon is in his 40s. It is not likely that they were ever primary school classmates. In addition, Okon, in reality, is a performer. Specifically, he performs comic roles in Nollywood movies (i.e. Nigerian home videos). Comedians usually distort realities or create alternative realities to instantiate humour in their audience. This popular image of Okon as a comedian subtracts from the truth-value of the implicated premise.

Based on the instances of counter-expectancy above, the reader derives humour from the text and invests more cognitive efforts to determine the latent rhetorical import of the meme. The campaign context, especially the accusation that Buhari had no requisite educational qualification to contest as president and his seemingly unconvincing defence of the allegation, guides the investment of more cognitive efforts. This informs the characterisation of the meme as a parody of Buhari's spurious attempts to defuse the allegation and yields the generated implicated conclusion that Buhari does not possess the required educational qualification to contest as Nigeria's president despite his having sworn to an affidavit that the original copy of his certificate was with the military board. The implicature leads to his framing as a criminal. Swearing to an untruth is perjury, that is, a criminal offence.

\subsubsection{Jonathan as propagandist}

A propagandist intentionally spreads deceptive information so as to aid a course which he supports or deems as being favourable to him. Meme creators present Jonathan as a propagandist with reference to his performance during his first term in office.

In the sample below (p.107), there is a cartoonish representation of Goodluck Jonathan. The meme presents him as an actor in a non-transactional action process. He gazes directly at the reader and addresses them. His use of a microphone suggests that the audience being addressed is fairly large. In front of him is a document containing his speech. The microphone he uses to address the audience is directly connected to a small generator which emits much smoke. This indexes the dysfunctional state of the generator's engine.

In addition to the non-transactional action process, he simultaneously performs the speech process. The quotation I will stabilize electricity, which receives much information value from its placement at the top of the image, indicates the content of his speech. Since the person to whom the utterance is attributed is Goodluck Jonathan, one employs reference assignment to determine the referents of $I$ and electricity. $I$ as a definite token refers intratextually to him 
(Jonathan) who has an iconic representation in the visual; electricity as an indefinite token refers to unstable power supply in Nigeria. To generate the explicature, one considers some contextual assumptions and the speaker's propositional attitude in context. The speaker, Goodluck Jonathan, was the incumbent president and presidential candidate of PDP seeking re-election. Therefore, one considers the speech as a campaign point. Electricity generation and distribution has been a sore point in the provision of utilities in Nigeria. Hence, Goodluck Jonathan presents it as a campaign agenda in his electioneering campaign. The explicature is: Goodluck Jonathan promises to stabilise electricity generation and distribution in Nigeria. The implicated premises are that Jonathan is a candidate for the presidential election and there has been a perennial electricity generation and supply problem in Nigeria.

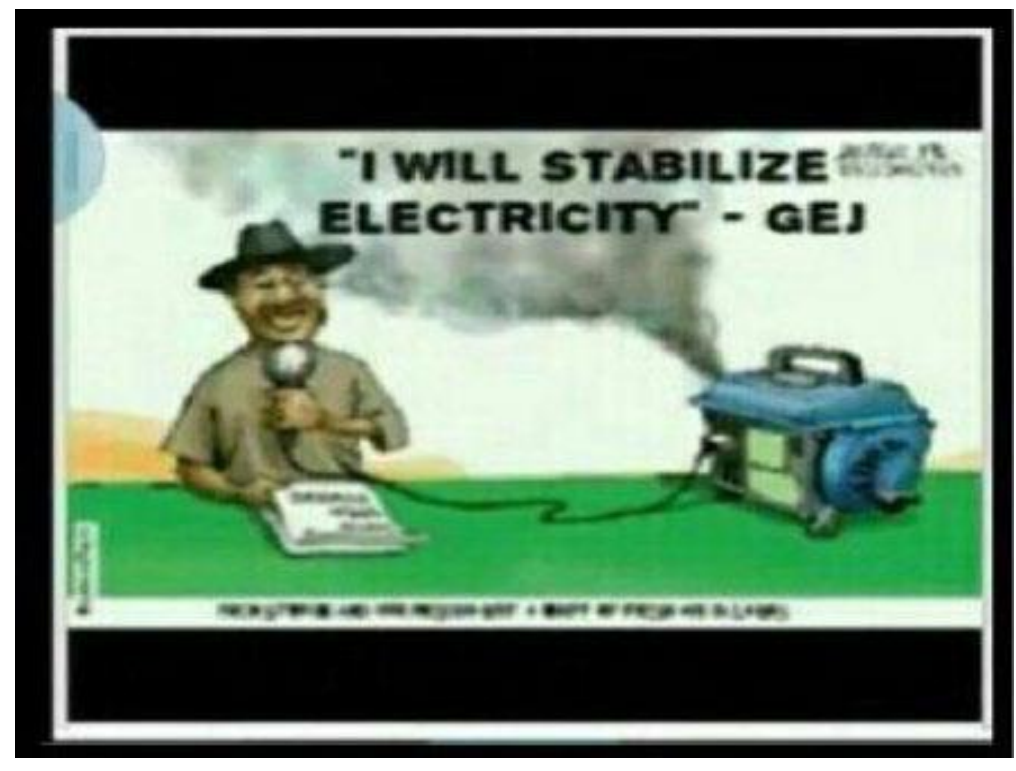

Text 3. Jonathan as propagandist.

The contextual implication is that Jonathan's promise to stabilise electricity supply in Nigeria is a ruse to hoodwink the electorate into voting for him for a second term. Accessible background information about Jonathan administration's unsuccessful efforts at improving power supply supports the implicated conclusion of the meme and the humour generated therein. In August 2010, Goodluck Jonathan launched a "Roadmap for Power Sector Reform" to end capricious power supply in Nigeria. Despite that scheme, unstable electricity supply still persisted. The meme achieves the implicated conclusion by first attenuating the conviction in his campaign promise. It indicates that he makes the promise with a microphone connected to a privately owned power generating set, not the public source of energy. The generating set playfully christened as I better pass my neighbour (I am better than my neighbour is) among the Nigerian population is associated with the Nigerian lower class. The lower class uses the energy generation set because the government which was headed by Jonathan could not provide stable electricity.

In addition, our contextual schema about outdoor campaigns of a Nigerian president who is seeking re-election (such events are usually elaborate public events in which state-of-the-art equipment are used and they are mostly funded through government resources) and the visual depiction in the meme are discordant. This contradiction generates humour and indicates him as lacking the competence to fulfil the enunciation. Humour emerges from this instance of incongruity. That the campaigner who had been president for five years runs his campaign with a diminutive and dysfunctional (as indexed by the thick smoke it emits) generating set 
invalidates his campaign point and portrays him as an election propagandist. He lacks the wherewithal to institute the changes he campaigns for and he only mouths the campaign point to deceive Nigerians into voting for him.

\subsubsection{Jonathan as unpopular candidate}

Some sampled memes present prognostic readings of the election result during the election campaign period. They variously present Jonathan as packing out of the presidential residence to his village, being welcomed back to the village by his people, and being put in prison after the election for his supposed act of misappropriation of resources while he was president. Text 4 stands as a representative sample of such memes:

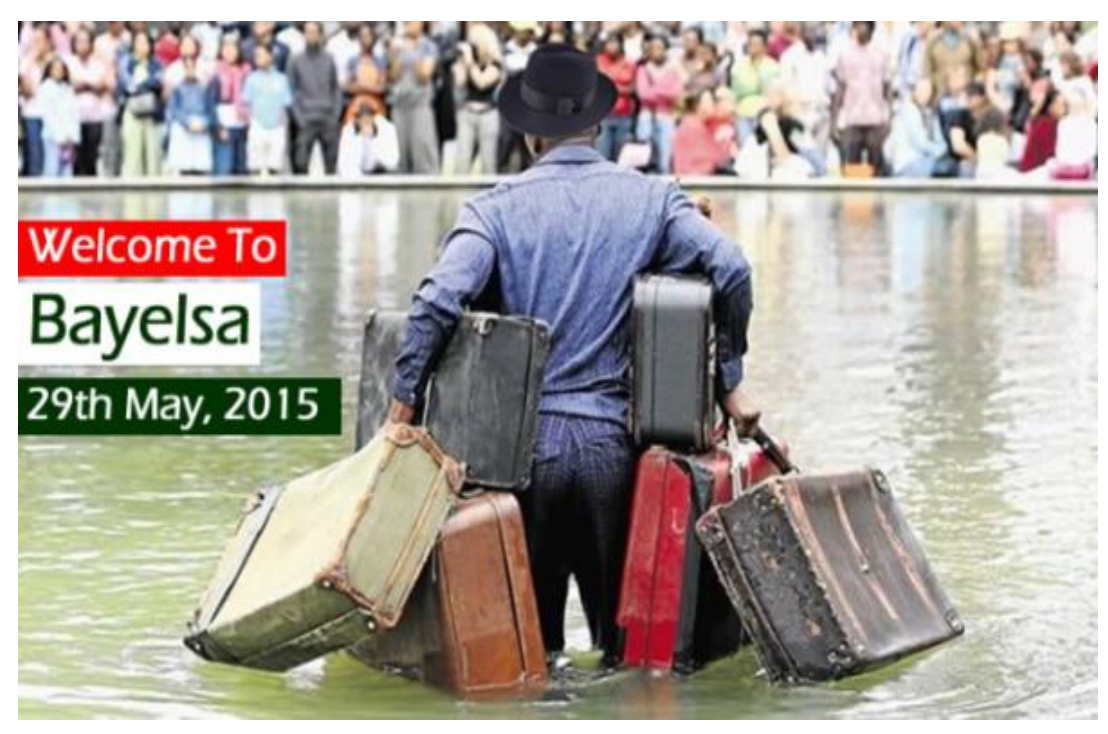

Text 4. Jonathan as unpopular candidate.

Text 4 contains the picture of a man who is crossing a river with his baggage. He backs the camera. The centralisation of the picture makes it the focus of attention. He walks through a body of water and faces a group of people who are at the riverbank. The man performs the non-transactional action process of crossing a river. Through entextualisation, the meme creator relocates it from an everyday context to the 2015 Nigerian election campaign context mainly through the verbal text accompanying the visual and some visual hints. There is a pictorial cue to the identity of the man. The man's cap is generally associated within Nigeria with the Niger Delta region. The meme puts the people at the riverbank at the background but activates them as performing a speech process. The utterance they make is Welcome to Bayelsa. The date 29th May, 2015 functions as a circumstantial element by indicating the time of the projected action. These linguistic expressions contribute significantly to the meme's recontextualisation. The logical form for the meme is: the people at the riverbank will welcome the man crossing the river to Bayelsa on 29 May 2015. They (the people) constitute the speaker and the intended receiver is the man walking in the river towards them. Through reference assignment and gap filling, one resolves the referents of the indexicals in the utterance. Bayelsa as a definite token is a state in Nigeria's south geopolitical zone; much of its territory is covered by water. 29 May, 2015 refers to the official date designated for the inauguration of the president to be elected in the 28 March 2015 presidential election. So, the Bayelsa people welcome back a man into their midst on 29 May 2015, namely the traditional date for presidential inauguration in Nigeria. 
To determine the man's identity, one collects more contextual information. Goodluck Jonathan was the only candidate in the 2015 presidential election from Bayelsa. The explicature derivable from the visual and the verbal texts is that Bayelsa people will welcome Jonathan back to Bayelsa from the Presidential Villa on 29 May 2015. In addition, the meme envisions that Jonathan would walk from Abuja to Bayelsa after losing the election through the waterways and he would bring back only his suitcases. That a former Nigerian president walks back to his hometown and with only his baggage brings out the humour in the text. It contradicts one's script of Nigerian ex-presidents. Their statuses as former presidents confer on them some privileges which, among others things, include access to chauffeur-driven cars. That Jonathan is an indigene of Bayelsa and a presidential candidate in the election stands as the implicated premise. If Jonathan is welcomed back to Bayelsa on 29th May 2015, instead of getting busy as the newly sworn-in president, it means he is not elected as president. The implicated conclusion is that Jonathan will lose the 2015 presidential election. A candidate who fails to win an election through popular votes is an unpopular candidate. Therefore, the implicit meaning supports the frame that Goodluck Jonathan is an unpopular candidate.

\subsubsection{Jonathan as criminal}

Most memes that project Jonathan as a criminal present him as having engaged in graft activities while in office as Nigeria's president. Jonathan served as Nigeria's president from 2010 to 2015. Text 5 below depicts the frame.

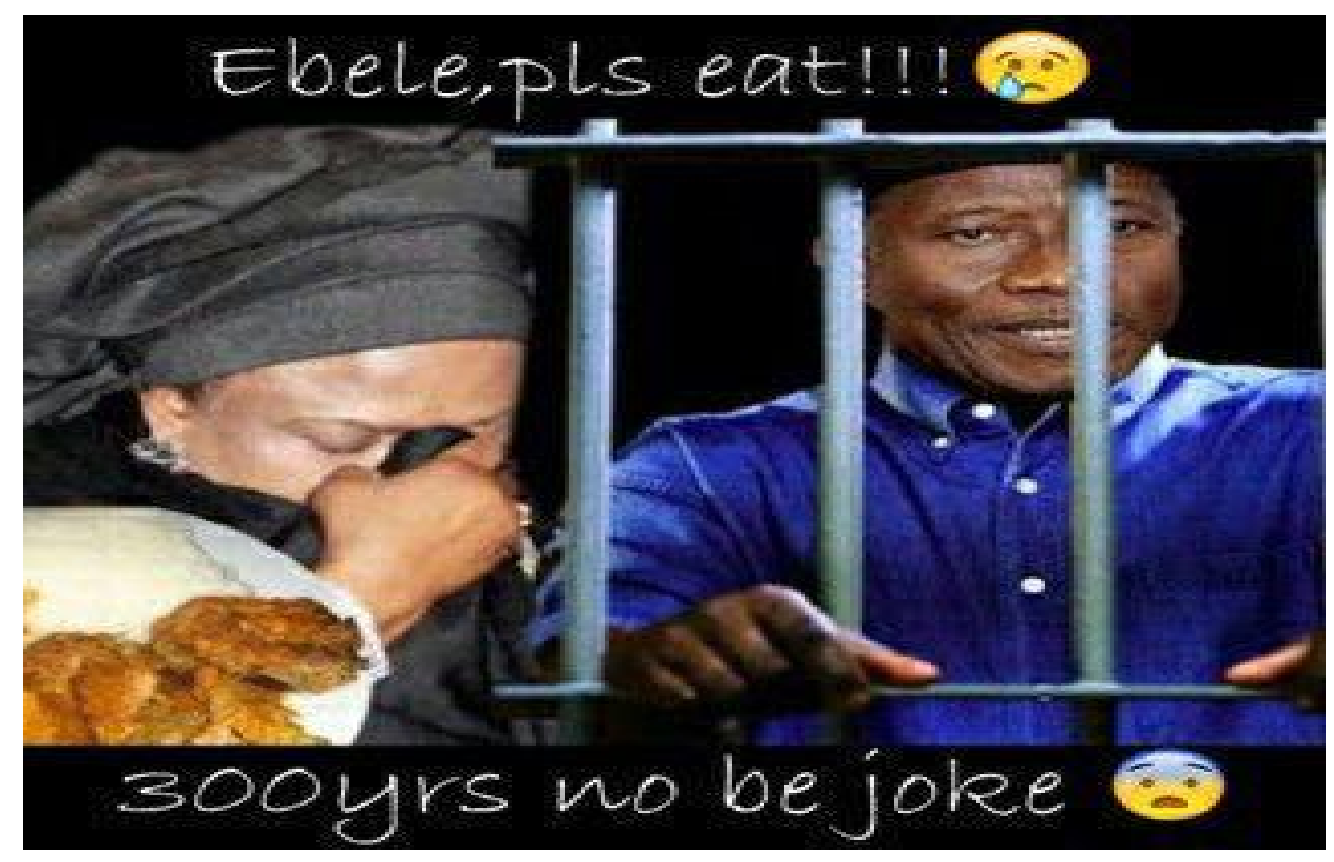

Text 5. Jonathan as criminal.

There are two participants in the visual image: Goodluck Jonathan and Patience Jonathan, his wife. The meme also works much on entextualisation. The meme juxtaposes two pictures from different sources. The image of Jonathan might have been significantly taken through some editing processes to achieve his positioning behind an iron gate. The meme superimposes the image of a food plate on the image of Patience Jonathan. Goodluck Jonathan performs a non-transactional reactional process by gazing outside the image. His face carries a grim expression indicating anguish and he holds on to the iron bar. The left of the frame has Patience Jonathan in black attire. She performs the behavioural process of sobbing and uses 
the tip of her black cloth to wipe her face. Her sob and the colour of her dress (black) symbolises her distraught mental state. She undertakes a speech process since the utterance Ebele, please eat. 300 years no be joke is allotted to her. She addresses Jonathan as the receiver of the utterance.

To explicate all referring expressions in the utterance, one requires more access to a campaign event which held during the 2015 presidential election campaigning. During a campaign tour, Patience Jonathan, the wife of Goodluck Jonathan, was reported to have begged the electorate to vote for her husband instead of Buhari, the candidate of the APC, who had promised to jail all previous corrupt leaders for 300 years if elected (Ugwuanyi 2015). In relation to the text of that campaign event, Jonathan is futuristically presented as having been imprisoned for graft activities that were perpetuated during his administration. 300 years indicates the number of years for which Jonathan has been assumedly sentenced. Ebele refers to Jonathan; the name is his middle name. Please eat makes an indirect reference (through bridging) to the picture of food in the text.

If we add the propositional attitude of the speaker to the inferential development above, the explicature generated is: Patience Jonathan implores Goodluck Jonathan to eat so as to survive the 300-year jail term to which he has been condemned. The instance of exaggeration in the explicit meaning generates humour in the meme. Stating that anyone would be jailed for 300 years for any offence contradicts one's script of legal processes and correctional facilities. No economic crime warrants being imprisoned for that number of years. Hence, one looks for the rhetorical value of the meme beyond the humour content. The explicit meaning portends the implicated premise that Goodluck Jonathan engaged in corrupt practices while in office and would be imprisoned for 300 years in the post-election era. That Jonathan is a corrupt leader and would be jailed for corruption in the post-election period stands as the implicated conclusion. Engaging in graft activities is a criminal offence. Both the implicated premise and the implicated conclusion lead to the frame of a criminal for Goodluck Jonathan.

\subsubsection{Jonathan as insensitive leader}

An insensitive public officer lacks the capacity to analyse the wave of general public opinions and evaluate his performance with reference to such. Where the memes present Goodluck Jonathan as an insensitive leader, his reactions to public opinions about his administration's performance deflect attention from the major issues at the nuclei of public opinions.

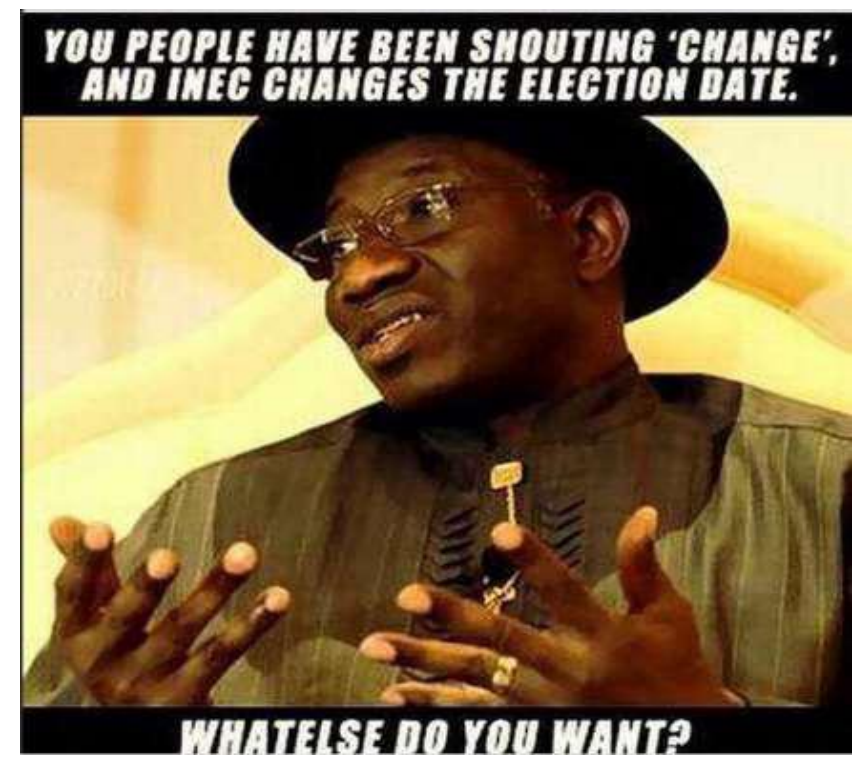

Text 6. Jonathan as insensitive leader. 
Goodluck Jonathan, the incumbent president and presidential candidate of the PDP during the campaign, is captured in a close-up shot; this foregrounds him as the major participant in the meme. He performs both the non-transactional action process and the speech process. He talks to another participant who is not represented in the meme. The text seems to have undergone minimal entextualisation. The image ensues from a political interview. However, the meme does not commute the gesture out of the interview context. It only places the gesture in relation to another topic. The meme creator imagines a topic that fits the gesture and is compatible with their rhetorical intention.

The meme attributes the verbal text You people have been shouting 'change' and INEC changes the election date. What else do you want? to Jonathan. You people as an indefinite token refers extratextually to Nigerians who had indicated their stance against Jonathan's government. INEC refers outside the text to the election management body in Nigeria and the election date as a definite token refers to the designated date for the 2015 general elections. You in the second sentence has an anaphoric relation with You people in the first utterance and the referents of You people are Nigerians. These exophoric reference assignments aid the inferential development of the logical form into an explicature.

During the campaign, APC, the major opposition party to the PDP-led government, had "change" as its major slogan. As the party gained much popularity in most regions of the country, its slogan became more popular. Hence, Jonathan's reference to Nigerians shouting "change" connotes the supposedly high level of popularity that APC enjoyed during the campaign period. Another related event to the meme above is the change in election date. INEC fixed the presidential election initially for 14 February 2017. Later on, the electoral management body postponed it to 28 March 2017 based on the advice of the security agencies. The explicature is that INEC has yielded to the people's request for "change" by changing the election date. The implicated premise is that the Nigerian people requested for a change in election date and the electoral management body has granted the request.

Here, Jonathan exploits the inherent ambiguity of "change" during the campaign period. The first reading of "change" in that context is its characterisation as the slogan of the opposition party, APC. In order not to indirectly affirm the popularity of this slogan which belonged to the major opposition party, Jonathan refuses to recognise that Nigerians' clamour for change represents their support for APC, the opposition party. Rather, he read their clamour to be a request for change in election date. This wrong reading of a popular movement against his government brings about the humour in the meme. His simplistic interpretation of a major political trend counters our script about the extent of information that a president has access to and results in humour. He has a barrage of political advisers and security networks that inform him about current political issues on regular basis. In addition, he is supposed to access the media regularly so as to update his knowledge about political events. The implicated conclusion is that Goodluck Jonathan is decidedly insensitive to public outcries.

\subsubsection{Positive individuated framing of political actors}

There is only one meme (Text 7) in which the created frame supports the political course of the represented candidate. Even in this singular occurrence, the opponent is still indirectly derided through the distortion of a biblical allusion by lexical substitution.

\subsubsection{Buhari as popular candidate}

A candidate is depicted as being popular in comparison to another. In samples representing Buhari as a popular candidate, he or his party are presented as having an edge over the 
candidate of the other parties, especially the candidate of the Peoples' Democratic Party (PDP). Text 7 below serves as a representative sample for memes with this frame:

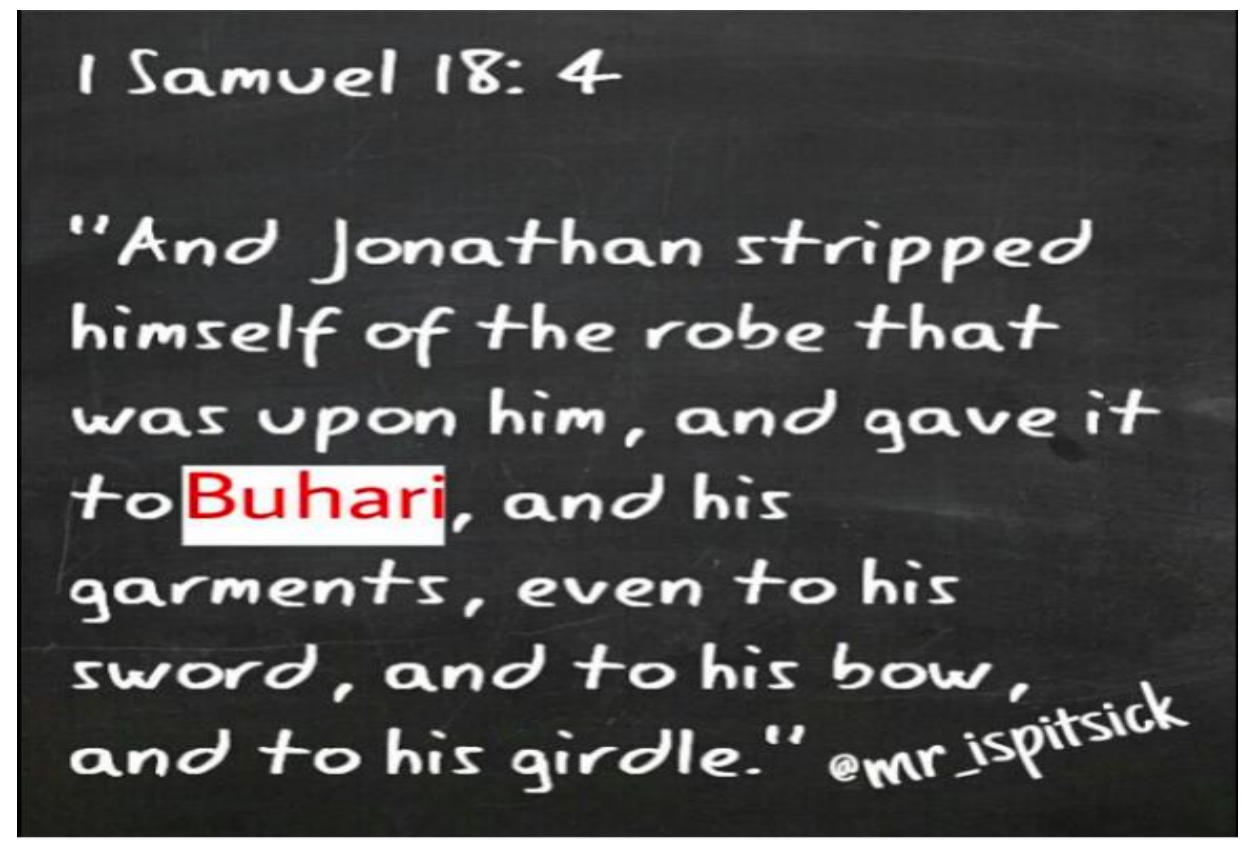

Text 7. Buhari as popular candidate.

The meme above recontextualises a biblical text in an electoral context. The original passage recounts David's first encounter with Jonathan. David had killed Goliath, a major enemy of the Israelites. Saul, the King of Israel, invited David to his palace and honoured him. Jonathan, the son of Saul, fell in love with David's heroic deed and became his friend. Jonathan gave the indicated items to David to mark their new friendship. The meme above significantly recontextualises the narrative in the context of the 2015 Nigerian presidential electioneering campaign and its humorous content emerges therein. In the 2015 Nigerian presidential election campaign, there were two major candidates: Goodluck Jonathan and Muhammadu Buhari. The name Jonathan already features in the bible passage. Since Buhari is not contained in the original version of the passage, the meme creator replaces David with Buhari. The meme generates humour by its appeal to the shared assumptions among its immediate audience (i.e. the Nigerian electorate) that Buhari is not a biblical name. Muhammadu Buhari is a Muslim from the predominantly Islamic northern Nigeria and the referenced bible verse does not contain the name Buhari. The meme foregrounds this instance of humour generation by giving perceptual salience to the instance of lexical substitution. The introduced lexical item Buhari is put in bold red letters on a white background.

When one employs extratextual reference assignment, one derives the explicature in the meme above. Jonathan and Buhari are definite tokens which refer extratextually to Goodluck Jonathan and Muhammadu Buhari. Goodluck Jonathan was the incumbent president in the election year. In addition, he was the presidential candidate of PDP. Muhammadu Buhari also stood as the presidential candidate for the major opposition party APC in the 2015 Nigerian presidential election. Other expressions such as his robe, his garment, his bow, and his girdle work as indefinite tokens with anaphoric relations to Jonathan.

Jonathan and Buhari become metaphorised as the biblical Jonathan and David respectively. However, in the context of a largely negative election campaign, this redefines the relationship between the biblical Jonathan and David. The biblical David and Jonathan were friends. But the meme here does not construe Buhari and Jonathan as friends. Rather, 
Buhari is regarded as being superior to Jonathan and Jonathan is compelled to strip himself of some property and give to Buhari. This act of giving, in the 2015 Nigerian electoral context, becomes a symbol of legitimised supremacy. Jonathan recognises the supreme electoral worth of Buhari and hands over some property to him. The property symbolises the Nigerian presidency. That Jonathan will hand over the presidency to Buhari emerges as the explicature. The meme projects that Jonathan, who was the Nigerian president at the time of the election, would relinquish the office to Buhari. The implicated premise is that Jonathan, as at the time of the campaign, held the office that both he and Buhari were contesting for. In a democracy, one gains or loses an office through popular votes. Buhari would gain the seat through polling more votes. The implicated conclusion of the meme is that Buhari would win the coming election. The implicated conclusion projects the frame of a popular candidate for Buhari since winning an election ensues from accruing as many votes as possible.

\subsection{Collective framing of political actors}

\subsubsection{Buhari and Jonathan as combatants}

A combatant engages in fights. Some of the memes represent the two major contestants in the 2015 presidential elections as combatants. This representation tallies with the metaphorisation of politics as war (see Charteris-Black 2004; 2011):

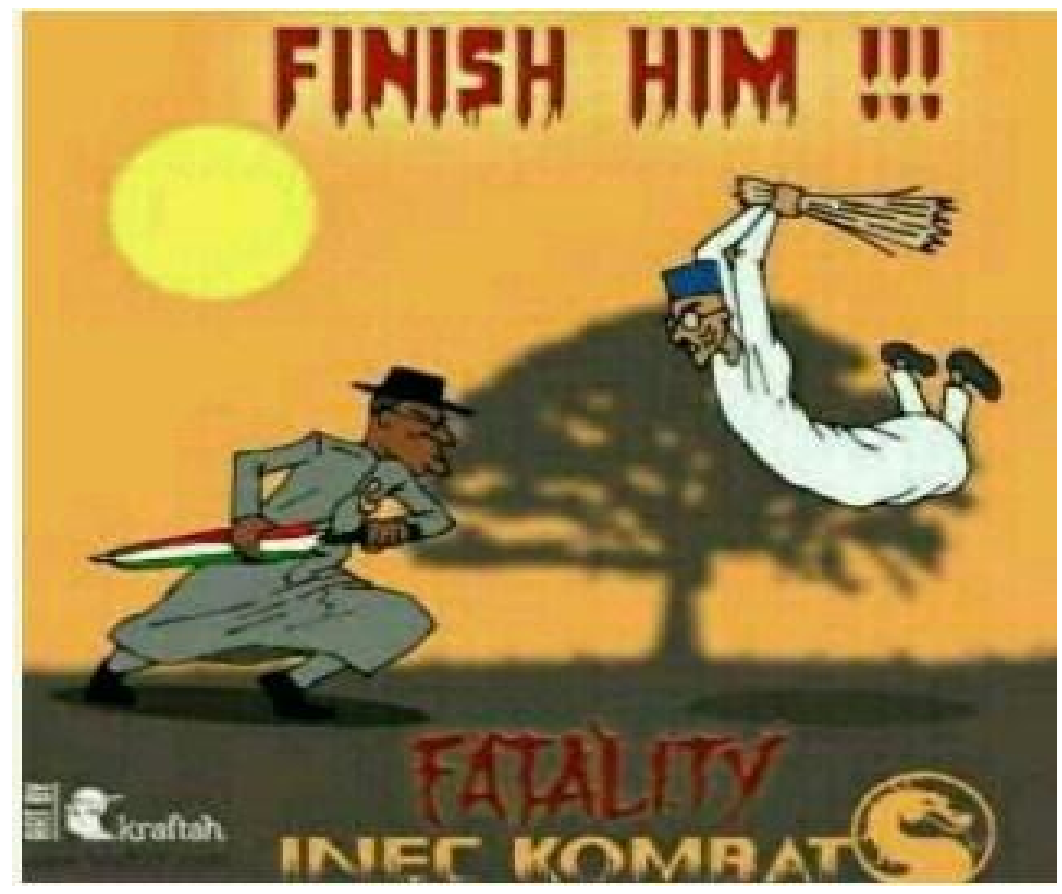

Text 8. Buhari and Jonathan as combatants.

There are two iconic cartoon characters above. The one on the left is Goodluck Jonathan and the one on the right is Muhammadu Buhari. Their mode of dressing and what they utilise as weapons in the duel further support their identification. They both wear the traditional attires associated with their ethnic affiliations. In addition, Jonathan uses an umbrella with three colours (red, white and green) as its combat instrument. The symbol of his political party (PDP) is an umbrella with the set of colours mentioned. Buhari fights with a broom. The major insignia of the party which Buhari represents is broom. 
Entextualisation contributes tremendously to humour generation and framing of social actors in this meme. The meme moves the two political contestants from the political campaign context to the entertainment context. The meme portrays them as combatants who engage in the contestation of force as characters in violent computer games do. Although there is a contextual transposition of the two actors from one frame to another, the idea of struggle underlies the two frames (election campaigns and violent computer games). The meme achieves entextualisation through semiotic resources such as the verbal texts (finish him, fatality, and INEC Kombat), the logo of the Mortal Kombat (a savage video game) and the combative postures of the actors. The verbal texts are expressions associated with Mortal Kombat. In addition, the replacement of Mortal with INEC underscores the movement from the political context to the video game context. Although politicians engage in struggle for votes during election campaigns, such contests only take place through argumentations. Extending such engagements beyond the contestation of ideas through deliberations to the deployment of brash force engenders humour. It contradicts one's cognitive models about civilised political contests.

As combatants in the meme, the two of them engage in a transactional action process: they fight each other. An unseen referee who performs a speech process urges the combatants to "finish" each other. In terms of reference assignment, him in FINISH HIM refers endophorically to either of the candidates. The voice urges them to "finish" (i.e. kill) each another. The colour of the letters (red) and their dripping of blood symbolises the expected fatal outcome of the fight: one contestant is expected to kill the other. The tripled exclamation marks at the end of the expressions also symbolically mark the emotionally charged nature of the combat between Jonathan and Buhari. The placement of the text atop the meme underscores its preponderance.

The texts at the bottom of the meme, namely FATALITY and INEC KOMBAT, also require further explication. INEC refers extratextually to the Nigerian election management organisation. Fatality and Kombat connect extratextually to a popular video game called Mortal Kombat. Its plot contains a duel between two realms: Earthrealm and Netherrealm. While the first universe Earthrealm is under the protection of a thunder god called Raiden and inhabited by heroes, Netherrealm is an inhospitable fiery abyss that is inhabited by demons and controlled by Emperor Shao Kahn. The Elder Gods stipulated that the occupiers of one realm must conquer the other realm through ten consecutive tournaments. Hence, the game is rife with violence. In the Mortal Kombat series, fatality is the last point in the fight where the potential victor in the finishing round inflicts a final brutal blow on their already decimated opponent; fatality is usually morbid. The game itself is referred to as Mortal Kombat. The meme substitutes Mortal with INEC to foreground the entextualisation of the text from the political context to the violent video game context, and likens the contestation for votes to a bloody duel between two animated characters in a violent video game. The explicated meaning is that Buhari and Jonathan are comparable to combative characters in the Mortal Kombat games. This metaphorisation accounts for the generated humour in this meme. The meme compares the two contesting political candidates to the combative characters in the Mortal Kombat video game. The implicated premise is that Buhari and Jonathan are intensely contesting for the presidential seat. The implicated conclusion is that Buhari and Jonathan are fierce competitors in the 2015 Nigerian presidential election. Their being likened to opposing characters in a violent video game and the generated implicated conclusion establish their frame as combatants, not just contestants. 


\section{Conclusion}

This study has investigated visual and verbal realisations of humour and typology of major political actors' frames in humorous Nigerian political memes that were created during the 2015 presidential election campaign. Its foundational argument is that humorous political memes doubly serve to create humour and latently perform the communicative purpose of framing political actors. The constructed frames are classifiable into two major classes: individuated and collective frames. The individuated frames portray the candidates separately. In the only collective frame, both candidates are presented as having a singular quality. The only collective frame is Buhari and Jonathan as combatants. Furthermore, the individuated frames diverge into two sub-branches: the negative frames and the positive frames. The six individuated negative frames (Buhari as incompetent candidate, Buhari as criminal, Jonathan as incompetent leader, Jonathan as propagandist, Jonathan as insensitive leader, and Jonathan as criminal) represent the candidates negatively. The only positive frame is Buhari as popular candidate. Through the preponderance of negative frames, meme creators sentimentally create adversative contexts for the presidential candidate they oppose. The parodying of the opposed candidate in a campaign context is intended to reduce their electoral values before the electorate. They magnify the weaknesses of such a candidate and vitiate their strong points. The latent communicative intention is to indirectly influence the electorate's voting behaviour.

The study has proposed an analytical model that explicates the humorous contents and communicative functions of election campaign memes. This can be employed or modified by subsequent researchers to account for humour and implicit meanings in memes in election campaign contexts, especially those of emerging democracies. It is evident from the study that humour does not defuse the rhetorical intentions of election campaign memes. Rather, memes simultaneously entertain and set perspectives on election candidates. In addition, the preponderance of negative frames supports the characterisation of the 2015 Nigerian presidential election campaign as highly negative (Nwofe 2015) and confirms the general metaphorisation of elections as combats for scarce resources (Musolff 2016). Even though the formation of a Nigerian online public has widened the scope of the Nigerian election discourse, it has not significantly transformed the quality of campaign discourses in Nigeria. The engagements of the Nigerian cyber public on election discourse encode, to a large extent, the political sentiments of its members; this tendency defrays from making election campaigns to be issue-based and nationalistic in dimension. To build a better democratic culture in Nigeria, civil society organisations, public opinion leaders, critics of democracy, the independent election management body, and politically unaffiliated statesmen should be more present in Nigerian online public space so as to further civic education on the core-repository of electioneering and the importance of differentiating cogent campaign issues from trivialities.

\section{References}

Adegoju, O. \& Oyebode, O. (2015). 'Humour as discursive practice in Nigeria's 2015 presidential election online campaign'. Discourse Studies 17 (6), pp. 643-662.

Attardo, S. and Raskin, V. (1991). 'Script theory revis(it)ed: joke similarity and joke representation model'. Humor: International Journal of Humor Research 4 (3/4), pp. $293-$ 347.

Attardo, S. (1997). 'The semantic foundation of cognitive theories of humour'. Humor: International Journal of Humor Research 10 (4), pp. 395-420.

Bauman, R., and Briggs, C.L. (1990). 'Poetics and performance as critical perspectives on language and social life'. Annual Review of Anthropology 19, pp. 59-88. 
Blakemore, D. (1992). Understanding Utterances: an Introduction to Pragmatics. Oxford: Basil Blackwell.

Brideau, K., \& Berret, C. (2014). 'A brief introduction to impact: the meme font'. Journal of Visual Culture 13, pp. 307-313.

Carston, R. (2002). Thoughts and Utterances: the Pragmatics of Explicit Communication. Oxford: Blackwell.

Charteris-Black, J. (2004). Corpus Approaches to Critical Metaphor Analysis. New York: Palgrave Macmillan.

Charteris-Black, J. (2011). Politicians and Rhetoric: The Persuasive Power of Metaphor. New York: Palgrave Macmillan.

Chen, K.W. (2013). 'The Singapore mass rapid transport: a case study of the efficacy of a democratized political humour landscape in a critical engagement in the public sphere'. European Journal of Humour Research 1(2), pp. 43-68.

Dzanic, N.D., \& Berberovic, S. (2017). '\#ForgiveUsForWeHaveSinned: conceptual integration theory and political internet humour'. European Journal of Humour Research 5 (2), pp. 4-22.

Entman, R. M. (1991). 'Framing U.S. coverage of international news: contrasts in narratives of the KAL and Iran air incidents'. Journal of Communication 41, pp. 6-27.

Filani, I. (2016). 'Laff wan kill me die: an analysis of Akpos jokes and readers' responses'. European Journal of Humour Research 4(4), pp. 5-25.

Freud, S. (1960 [1905]). Jokes and their Relation to the Unconscious (J. Strachey, Trans.). New York: W. W. Norton.

Giaxoglou, K. (2009). 'Entextualizing vernacular forms in a Maniat village: gestures of orthopraxy in local folklore practice.' Pragmatics 19 (3), pp. 419-434.

Huttington, H. (2016). 'Pepper spray cop and the American dream: using synecdoche and metaphor to unlock internet memes' visual political rhetoric'. Communication Studies 67 (1), pp. 77-93.

Kress, G., and van Leeuwen, T. (1996). Reading Images: the Grammar of Visual Designs. London: Routledge.

Kuypers, J. A. (1997). Presidential Crisis Rhetoric and the Press in the Post-Cold War World. Westport, CT: Praeger.

Kuypers, J. A. (2002). Press Bias and Politics: How the Media Frame Controversial Issues. Westport, CT: Praeger.

Kuypers, J. A., Cooper, S., \& Althouse, M. (2008). 'The president and the press: the framing of George W. Bush's speech to the United Nations on November 10, 2001'. The American Communication Journal 10 (3), pp. 1-23.

Kuypers, J. A. (2009). 'Framing analysis', in Kuypers, J.A. (ed.). Rhetorical Criticism: Perspectives in Action, London: Lexington Books, pp. 181-204.

Kuypers, J. A. (2010). 'Framing analysis from a rhetorical perspective', in D'Angelo, P. \& Kuypers, J.A. (eds.). Doing News Framing Analysis: Empirical and Theoretical Perspectives. New York: Routledge, pp. 287-313.

Martin, J.R., \& White, P.R.R. (2005). The Language of Evaluation: Appraisal in English. New York: Palgrave Macmillan.

Milner, R. M. (2013). 'Pop polyvocality: internet memes, public participation, and the Occupy Wall Street movement'. International Journal of Communication 7, pp. 2357-2390.

Musolff, A. 2016. Political Metaphor Analysis: Discourse and Scenarios. London: Bloomsbury.

Nerhardt, G. (1976). 'Incongruity and funniness: Towards a new descriptive model, in Chapman, A.J. and Foot, H.C. (eds.). Humour and Laughter: Theory, Research and Applications. Oxford: John Wiley \& Co. 
Nnochiri, I. (2015). 'Certificate saga: why court struck out suit against Buhari'. Vanguard, 30 June, 2015. [Online] www.vanguardngr.com/2016/06/certificate-saga-court-struck-suitbuhari/. [Accessed 27 August, 2017.]

Nwofe, E. (2015). 'Dimensions of negativity in the coverage of the Nigeria's 2015 presidential election'. International Journal of International Relations, Media and Mass Communication Studies 2 (2), pp. 6-29.

Shifman, L., Coleman, S. \& Ward, S. (2007). 'Only joking?: online humour in the 2003 UK general elections'. Information, Communication and Society 10 (4), pp. 465-487.

Shifman, L. (2013). 'Meme in a digital world: reconciling with a conceptual troublemaker'. Journal of Computer Mediated Communication 18, pp. 362-377.

Shifman, L. (2014). Memes in Digital Culture. Cambridge, Massachusetts: MIT Press.

Silverstein, M., \& Urban, G. (eds.). (1996). Natural Histories of Discourse. Chicago: University of Chicago Press.

Sperber, D., \& Wilson, D. (1986) Relevance: Communication and Cognition. Oxford: Basil Blackwell.

Tay, G. (2014). 'Binders full of LOLitics: political humour, internet memes and play in the 2012 US presidential election (and beyond)'. European Journal of Humour Research 2(4), pp. 46-73.

Ugwuanyi, S. (2015). “I'm not ready to feed my husband in prison", Patience Jonathan'. Daily Post, 17 March, 2015. [Online] http://dailypost.ng/2015/03/17/im-not-ready-tofeed-my-husband-in-prison-patience-jonathan/. [Accessed 27 August, 2017.]

van Leeuwen, T. (2003). 'A multimodal perspective on composition', in Ensink. T., \& Sauer, C. (eds.) Framing and Perspectivising in Discourse. Amsterdam: John Benjamins.

van Leeuwen, T. (2008). Discourse and Practice: New Tools for Critical Discourse Analysis. Oxford: Oxford University Press.

Wilson, D. (1994). 'Relevance and understanding', in Brown, G., Malmkjaer, A.P. and Williams, J. (eds.), Language and Understanding. Oxford: Oxford University Press, pp. $35-58$.

Yus, F. (2003). 'Humour and the search for relevance'. Journal of Pragmatics 35, pp. 12951331.

Yus, F. (2004). 'Pragmatics of humorous strategies in El club de la comedia', in Reita, R.M. \& Placencia, M.E. (eds.), Current Trends in the Pragmatics of Spanish, Amsterdam: John Benjamins. pp. 319-346. 